\title{
Recitation of Surah al-Insyirah and al-Qadr in the Bayen Tradition Based on Peter L. Berger Sociology of Knowledge Perspective
}

\author{
Annisa Fadlilah \\ UIN Sunan Kalijaga Yogyakarta, Indonesia \\ aelhasby@gmail.com
}

\begin{abstract}
This study discussed the response of the Wonokerto community to the Quran, dealing with the recitation of Surah al-Insyirah and al-Qadr in the Bayen tradition. This research, which belongs to the Living Quran area, is interesting because the use of both surahs on Bayan tradition is rare. The principal issues that will be answered in research is how the implementation of Bayen tradition as well as transmission and transformation practice of reciting surah al-Insyirah and al-Qadr in Bayen tradition using Peter L. Berger Sociology of knowledge theory. The dialectical triad in Peter L Berger's sociology of knowledge consists of externalization, objectivity and internalization produced the following research conclusions: The transmission of reciting surah al-Insyirah and al-Qadr in the Bayen tradition originated from the process of externalizing the knowledge of the kiai (Islamic leaders) namely KH Dahlan, KH Zaenuri and Kiai Nurul Huda about the practice of the tarekat obtained through ijazahs and then passed on to the general public. People who tend to obey their teachings accept the practice and implement it together so that the practice experiences an objectivity process into an agreed tradition. Society as the perpetrators of tradition has their own internalization which is subjective about the meaning and motivation of doing the deeds, including for protection from negative things, as a non-material strength for pregnant women, as a deterrent to lust, and so forth. While the transformation of this practice occurred because of differences in externalization experienced by Kiai Dahlan and Kiai Nurul Huda who were met with different conditions in society. This practice of deformation took the form of omitting the recitation of manaqib and was only replaced by reciting surah al-Insyirah and al-Qadr which were previously surahs recited as etiquette before reciting the manakib
\end{abstract}

Keywords: Living Quran, Bayen Tradition, Sociology of Knowledge, Peter L Berger

\begin{abstract}
Abstrak
Penelitian ini membahas tentang respon masyarakat Wonokerto terhadap al-Qur'an, yaitu dalam pembacaan surat al-Insyirah dan al-Qadr pada tradisi bayen. Penelitian yang termasuk ranah living Qur'an ini menarik karena meskipun tradisi bayen yang terjadi di Wonokerto ini terdapat penggunaan kedua surat tersebut terbilang langka. Pokok-pokok persoalan yang akan dicari jawabannya dalam penelitian ini adalah bagaimana pelaksanaan tradisi bayen serta transmisi dan transformasi amalan pembacaan surat al-Insyirah dan al-Qadr dalam tradisi bayen dengan menggunakan teori sosiologi pengetahuan Peter L Berger. Triad dialektis dalam sosiologi pengetahuan Peter L Berger yang terdiri dari eksternalisasi, objektivasi dan internalisasi menghasilkan kesimpulan penelitian sebagai berikut: Transmisi amalan pembacaan surat al-Insyirah dan al-Qadr dalam tradisi bayen berasal dari proses eksternalisasi pengetahuan dari para kiai yaitu K.H. Dahlan,
\end{abstract}


Millatī, Journal of Islamic Studies and Humanities, Vol. 4, No. 2, Desember 2019: 185-207

K.H. Zaenuri dan Kiai Nurul Huda tentang amalan tarekat yang didapatkan melalui ijazah dan selanjutnya disampaikan kepada masyarakat umum. Masyarakat yang cenderung manut dawuh kiai menerima amalan tersebut dan melaksanakannya bersama sehingga amalan tersebut mengalami proses objektivasi ke dalam sebuah tradisi yang disepakati. Masyarakat sebagai pelaku tradisi mempunyai internalisasi masing-masing yang bersifat subjektif tentang makna dan motivasi melakukan amalan tersebut, diantaranya untuk perlindungan dari hal-hal negatif, sebagai kekuatan non-materi untuk ibu hamil, sebagai penghalau hawa nafsu, dan lain sebagainya. Sedangkan transformasi amalan ini terjadi karena perbedaan eksternalisasi yang dialami kiai Dahlan dan kiai Nurul Huda yang dipertemukan dengan kondisi masyarakat yang berbeda pula. Transformasi amalan ini berupa peniadaan pembacaan manakib dan hanya digantikan dengan membaca surat al-Insyirah dan al-Qadr yang sebelumnya menjadi surat yang dibaca sebagai adab sebelum membacakan manakib.

Kata Kunci: Living Qur'an, Tradisi Bayen, Sosiologi Pengetahuan, Peter L Berger

\section{INTRODUCTION}

The presence of the Quran in the midst of society gives rise to different responses from one another. Included in this response are traditions that exist in Wonokerto Village, Bancak District, Semarang Regency, namely the tradition of reciting al-Insyirah and al-Qodr in the Bayen Tradition. The Bayen tradition is interpreted as anything related to a baby, from the womb to birth to the world. The practice of reviving the Quran in this tradition is carried out by reciting the two surahs on Kapatan, ${ }^{1}$ Mitoni ${ }^{2}$, brokohan, ${ }^{3}$ and others and routine recitations every day before sunset.

With a society of $100 \%$ Muslim, this tradition is a form of religious behavior that is manifested by the community as a result of the teachings they get from religious leaders. The tradition that uses the Quran in certain times can be interpreted as a way of people in Living the Quran in everyday life or known as the Living Quran ${ }^{4}$. The study of Living Quran can be interpreted as a study of various social events related to the presence of the Quran or the existence of the Quran in a particular community. ${ }^{5}$ Other researchers state that the study of the Living Quran is the study of the Quran but does not rely on its textual existence, but rather the study of social phenomena that are born

\footnotetext{
${ }^{1}$ Traditions commemorate the age of four months of pregnancy. This tradition is usually carried out Friday wage which is close to the age of the fourth month of pregnancy.

2 Traditions commemorate the age of seven months of pregnancy. Usually this tradition is carried out on Friday Wage which is close to the seventh month of pregnancy.

3 The slametan tradition held after the baby is born and returns home as a form of gratitude for the safety and birth of the baby.

4 Sahiron Syamsudiin, "Research Areas in the Study of the Quran and Hadith" Research Methodology for Living Quran and Hadith ", ed. Mansur, et al, cet. I, (Yogyakarta: TH-Press, 2007), p. xi-xvi.

${ }^{5}$ Mansur, Living Quran in the History of Quran Study " Ibid., p. 8.
} 
related to the presence of the Quran in certain geographical areas and time anyway. ${ }^{6}$ The practice of interpreting the Quran in this study is not based on its textual message, but rather the presumption that there is a "fadlilab" from certain units of the Quranic text for the sake of practical praxis in everyday life.

This religious behavior was preserved by the community since it was taught by KH Dahlan as a religious figure and leader of the tarekat in Wonokerto Hamlet, and continued by his successor until now by kiai Nurul Huda. The recitation of these two surahs was originally part of the etiquette before reciting the manakib of Sheikh Abdul Qodir al-Jailani commonly recited in the Bayen tradition. Later, this tradition experienced a difference in which the two surahs became separate recitation without including manakib. ${ }^{8}$

Looking back, the tradition taught by Kiai Dahlan originated from his teacher by giving a ijazah. ${ }^{9}$ The ijazah granted to continue teaching through this tarekat does not stop at the congregation only, but extends to the surrounding community. This tradition is still alive today because the community considers that reciting the two surahs to their children is a form of business of parents who want their children to have good morals. The community has the belief that if this is an ijazah from a kiai who in fact understands more about religion and has experienced spiritual experiences that not just anyone can get, then by doing so it is expected to get the goodness of obedient to kiai's teaching. ${ }^{10}$

This tradition certainly does not appear without a cause because in it there is a certain sorting of surahs that are recited. In contrast to what generally happens where the surahs of Maryam and Yusuf are common recitation for pregnant women, in this hamlet it is al-Insyirah and al-Qadr that are encouraged to recite in the moments of Bayen. There have been many previous studies on the recitation of certain surahs in traditions such as ngapati, mitoni, or tingkeban relating to infants, but on average they use the surahs of Yusuf, Maryam, Yasin, but no one has used Surah al-Insyirah and alQadr in tradition Bayen. This social phenomenon makes the researcher interested to study further.

It is necessary to search how the process of socializing this tradition from generation to the next generation in which the reading of the two surahs initially as a witness before reading the manakib, while in its development it is precisely these two verses which become the main by

\footnotetext{
${ }^{6}$ Muhammad Yusuf, "The Sociological Approach in Living Quran Research " Ibid., p. 36-37.

${ }^{7}$ Mansur, "Living Quran", p. 4.

${ }^{8}$ Muhammad Yusuf, "The Sociological Approach in Living Quran Research " Ibid., p. 36-37.

9 Permission granted by the teacher to his students to teach the knowledge that the student gets from his teacher. See https://www.kbbi.web.id/iyah access on 30 January 2018

${ }^{10}$ Following what the kyai taught.
} 
Millatī, Journal of Islamic Studies and Humanities, Vol. 4, No. 2, Desember 2019: 185-207

overriding the reading of the manakib. The researcher's research is included in the study of Living Quran because the selection of surah al-Insyirah and al-Qadr in this tradition is not based on the textual side but other factors.

Broadly speaking, Surat al-Insyirah starts its verses by describing the gift of peace of mind obtained by Muhammad and concludes with instructions that can lead someone to obtain that calm. ${ }^{11}$ Narrated in the hadith about sabab an-nuzul where this surah was revealed when the

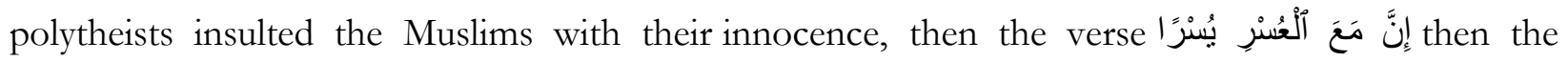
Apostle also preached the glad tidings to his people:

Said: Descended when the polytheists insulted the Muslims with poverty. And issued by Ibn Jarir from alHasan, be said: when the verse "inna ma'a al-'usri yusro came down" Rasulullah $S A W$. said: "you are happy, you have come to ease, there will never be a tribulation that defeats two conveniences". ${ }^{12}$

Surah al-Qodr tells about the glory of one of the nights in Ramadan called Laylat-al Qadr, in which the Quran was revealed to the world for the first time. In this surah, it is illustrated how from that night the figure is better than a thousand months. Apart from the different commentaries in interpreting the thousand words, this surah is a night witness glorified by Allah with various glory as a tribute to the descent of the Quran, including the fall of angels in charge of all the affairs of the world. ${ }^{13}$ While Sabab an-nuzul this surah is contained in a hadith:

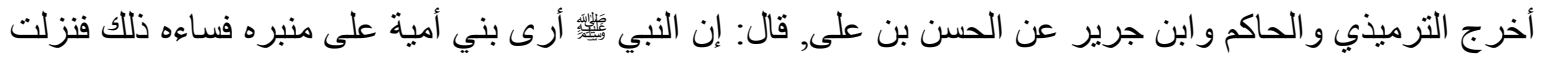

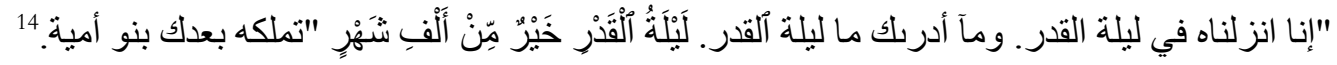

$$
\begin{aligned}
& \text { Narrated by at-Tirmizi, Hakim and Ibn Jarir from al-Hasan ibn 'Ali, said: verily the Prophet }
\end{aligned}
$$

\section{METHODOLOGY}

This research is a Living Quran study where this research looks at the phenomenon of recitation of surah al-Insyirah and al-Qadr in Bayen not based on textual only, but on the fadlilab (benefits) in both surahs. The dialectical triad in Peter L. Berger's Sociology of knowledge is useful to see how the transformation and transmission of knowledge of the tradition from the beginning, namely based on ijtihad from the kiai who carry out externalization, habituation of people who accept the teachings

11 Quraish Shihab, Tafsir al-Misbah; Message, Impression and Harmony of the Qurans cet. V, Vol. 15 Jakarta: Lentera Hati, 2002), p. 423.

12 as-Suyuti, Asbab an-Nuzul, volume II, (Cairo: Dar al-Fajr li at-Turats, 2010), p. 460.

13 Ali ash-Shobuni, Sh ofwatu at-Tafâsîr, Volume III, cet. X, (Cairo: Dar ash-Shobuni, 1980), p. 564.

14 As-Suyuti, Asbab an-Nuzul, p. 464. 
and practice in a tradition that is objectified and the meaning of each individual people who internalize the tradition.

This research on social phenomena uses the dialectical triad theory framework in the Peter L Berger's sociology of knowledge which consists of externalization, objectivity, and internalization that are dialectically related in describing what happens in society. Phenomenology of Max Scheler and Alfred Schutz, which departs from individualized activities which are externalized from intersubjectivity between individuals in society, forms the basis of this theory. ${ }^{15}$ Phenomenology examines the reality of daily life as the main reality of community symptoms. The reality of life is in the form of the overall interaction of activities between individuals which reflects the existence of knowledge and experience in that interaction. Knowledge and experience are sourced from various norms, ranging from morality, myths, and religious norms. ${ }^{16}$ Berger thinks that the reality of the human being in doing some things goes through three stages of the process of elements outside themselves), objectified (elements outside individual but affects the motion of people), and the latter is the internalization process in which case it affects the individual. The three processes can gradually display comprehensive results in a social study. ${ }^{17}$

Society, according to Berger, is a product of human activity which then acts back to form its creator, or in other words humans produce society and society produces humans. These two statements do not contradict each other but become a unity in the dialectical movement of society through an endless process of externalization, objectivity and internalization. ${ }^{18}$ In other words there is a dialectical process between humans as an instrument that creates social reality and at the same time is influenced by the results of his creation.

In a broader insight, by viewing society as a process that takes place in these three moments and the problem of legitimacy with cognitive and normative dimensions, then social reality is nothing but a social construction made by the community itself in its historical journey from past to present to the future. front through an ongoing process of socialization. ${ }^{19}$ Specifically for religious communities, this society is also a product of religious people and will provide feedback to producers, or in other words, shape religious people. As a product of religious people, the society

15 Irving M. Zeitlin, Re-Understanding Sociology; Criticism of Contemporary Sociological Theory, (Yogyakarta: Gajah Mada University Press, 1998), p. 259-266.

16 Koentjaraningrat, Introduction to Anthropology, (Jakarta: Aksara Baru, 1989), p. 112.

17 Muniroh, Nisfu Sya'ban in the Traditions of the Banjar Society (Living Studies Hadith Perspective of the Sociology of Knowledge Peter L.Berger), Journal of Al-Risalab Volume 13, Number 1 January-June 2017 , p . 2

18 Peter L Berger and Thomas Luckman, Social Interpretation of Reality, hhm. Hasan Basari, (Jakarta: LP3ES, 2013), p. 83.

${ }^{19}$ Ibid., p. 91. 
Millatī, Journal of Islamic Studies and Humanities, Vol. 4, No. 2, Desember 2019: 185-207

which is analogous to being a small and complete universe is formed from human activities and consciousness originating from religion. ${ }^{20}$ In the dialectical triad Peter $\mathrm{L}$ Berger, there are three moments that become the keywords for the realization of a social order, namely

The first is externalization. The process of externalization is the continuous outpouring of human activities in the world, both physical and mental. ${ }^{21}$ Humans do not live in a vacuum, human self will go out into the world where he lives. Human beings will instinctively build interactions with their world. He will express his existence in activities outside of himself.

Humans also create values and norms by which they are able to create meaning and behavior patterns that regulate life socioeconomically, culturally and religiously. ${ }^{22}$ In other words the values prevailing in society are human creations which at the same time creates patterns of human behavior. In Berger's view, humans can get out of the tyranny that ensnared it by means of transformation. ${ }^{23}$ Externalization process such as what happened in the tradition of reciting al-Insyirah and al-Qadr in the Bayen tradition will answer how this tradition was formed in the beginning and who introduced it to the community. Both of these surahs are from the word of God, obviously it cannot be called a human product, but the meaning and response to it become a separate product produced by humans that will later influence their religious behavior patterns that manifest in an activity or routine.

The second is objectivity. objectivity is the moment when the results of human activity express themselves as objective reality that must be faced by the creator as something outside and forceful. ${ }^{24}$ The results of human externalization then become an objective reality through the institutionalization process that begins with the process of habituation. After becoming a habit, this behavior will settle into a tradition that is no longer seen as a result of human creation, but rather is seen as something that should have existed and carried out by its creator, namely humans. In the Bayen tradition the recitation of Surah al-Insyirah and al-Qadr also undergoes an objectification process so that the tradition can be carried out and known until the present generation. In other words, the objectivity of this tradition can be seen from how people carry out the practice of reading the two surahs to become a tradition that is agreed upon and carried out together.

The third is internalization. At this stage humans do re-absorption of the same reality by humans in subjective awareness. ${ }^{25}$ In other words, the process of absorption into the human consciousness objectivity is such a way that the structure of this world determine the subjectivity of

20 Amin Abdullah, Religious Studies; Normativity or Historicity, (Yogyakarta: Student Library, 1996), p. 9.

${ }^{21}$ Peter L Berger, Sacred Heaven, Religion as a Social Reality, tjmh. Hartono, (Jakarta: LP3S, 1994), p. 4-10.

22 Mohamad Dimyati, "Al-Quran as Social Reality" (Sociological Study of the Muslim Community of SukorejoTrenggalek Village), Thesis of UIN Sunan Kalijaga, 2009. Thesis not published, p. 16

${ }^{23}$ Ernita Dewi, Social Transformation and Religious Values, Journal of Substance, Vol. 14 no. April 1, 2012, p. 234

${ }^{24}$ Peter L Berger and Thomas Luckman, Social Interpretation of Reality, p. 83.

25 Ibid. p. 83 
consciousness itself. ${ }^{26}$ In this process the objectified social world is put back into human consciousness during the process of socialization to be responded back subjectively. After experiencing objectivity in the form of tradition, the people of Wonokerto certainly have their respective meanings of the reading of the two choice surahs in the Bayen tradition. Internalization of each individual is excavated not to punish right or wrong, because each individual has their respective rights in viewing a phenomenon.

With the three existing processes in Peter L. Berger's dialectical triad, this will become a knife for analyzing how a tradition or religious behavior can exist and is deeply rooted in a society, which in this study is the Wonokerto community, Semarang Regency. With this the researcher wants to analyze how the construction of public knowledge about surah al-insyirah and al-Qadr recited in the Bayen tradition which still survives.

\section{RESULT AND DISCUSSION}

\section{Understanding of the Bayen Traditions and the Like}

The process of the creation of man has important moments of the community of Java specifically commemorated with ceremonies. This is an effort to synchronize the physical and spiritual elements, so that it is expected to create perfect human beings both physically and spiritually. For the Javanese Muslim community, special rituals that match the process of human creation are carried out as a form of devotion and sincerity of worship to Allah. Ritual symbols are expressions of an understanding of 'unreached reality. ${ }^{27}$ The ritual performed both during pregnancy until birth are subsequently called the Bayen ritual .

The word Bayen when translated into Indonesian means birth. ${ }^{28}$ In Javanese, especially those used in Wonokerto Hamlet itself, this word is not only meant to give birth but all things related to babies. The researchers borrow this term to represent all the traditions related to the existence of a baby, both from still in the womb and after birth. These rituals such as neloni, ngapati, mitoni, nyangani, brokohan, sepasar, puputan, akikah, and other moments that differ from one region to another.

\footnotetext{
26 Ibid., p. 19-23.

${ }^{27}$ Muhammad Sholikhin, Rituals and Traditions of Javanese Islam, (Yogyakarta: NARASI, 2010), p. 49

28 https://kamuslComplete.com/kamus/jawa-indonesia/arti-kata/Bayen, accessed on 15 December 2017
} 
Millatī, Journal of Islamic Studies and Humanities, Vol. 4, No. 2, Desember 2019: 185-207

The creation of a human body until a spirit is blown that makes it live through a process that is not short. A description of the process of the creation of a whole human being contained in several verses of the Quran, including Surat al-Mukminun: 12-14.

"Indeed, we have created man from a essence (derived) from the ground. Then We make the essence of semen (stored) in a sturdy place (womb). Then we made the semen a blood clot, then the blood clot, we made a lump of meat, and the lump of meat we made into bones, then we wrapped the bones in flesh. We then made bim another (shaped) being. Then the holy time of Allah, the best Creator (QS.23: 12-14).

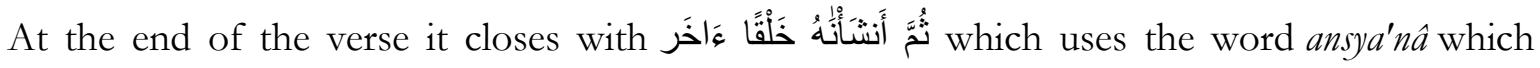
implies that this final process of human events is completely different in nature, character, and situation from the previous phases, because the word implies manifesting something and maintaining and educating it. ${ }^{29}$ In other words the gradual process of human creation does not only give birth to a physical body, but is complemented by the non-physical potential that follows it.

Information about human events in the womb is then given additional information in more detail from Rasulullah SAW, namely the existence of provisions and certainty of his life by God, especially relating to his fortune, age, and fate in the world which has been announced since in the womb.

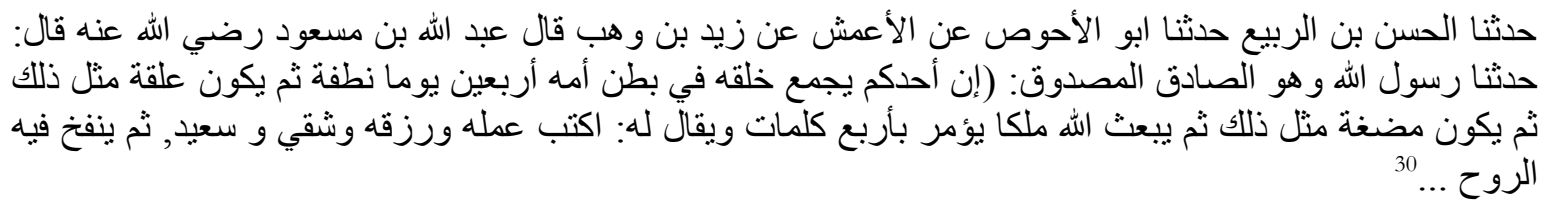
"Having told us al-Hasan bin ar-Robi', told us Abu al-Ahwash from A'masy and Zaid bin Wahab that Abdullah bin Mas'ud said: Rasulullah SAW as the honest human being and is believable said:" The incident of one of you was collected in the stomach of his mother for forty days, as sperm, even the second forty days formed a clot of clotted blood. When even the third forty days were swapped into lumps of meat. Then Allah sent an angel with four sentences and said: write good deeds, good fortune, (good luck) and then blow the spirit $\cdots$

Hadith provides an explanation that there are important events in human life that will inevitably occur, namely when his birth, when his life is taken with death and when he is resurrected in accountability. Of the three critical issues in the discussion this time the researchers will only talk in one thing, namely human birth, which in the process of its creation also passes important events.

Javanese Islamic traditions at every time there is a change in the cycle of human life, on average they hold a slametan or wilujengan (Javanese celebration for any occurance) by using various kinds of food as a symbol of appreciation of human relations with God. Especially in the process of

${ }^{29}$ Quraish Shihab, Tafsir al-Misbah, vol. 8, p. 339.

30 Hadith no. 3208, "Kitab bada'a al-Kholaq", Abi Abdillah Muhammad ibn Ismail al-Bukhori, al-Jami 'așȘobih, Volume 2, (Cairo: al-Mațba'ah as-Salafiyah), p. 424 
the birth of a new creature into this world, of course, colored with various slametan. With these symbols it is felt that God is always present and integrated with individual lives. Attempts to approach God through slametan, kenduri (festivity) or sedekahan (alms) are intended as spiritual negotiation efforts, so that all supernatural things that are beyond the limits of human ability will not touch them negatively. ${ }^{31}[$

Wonokerto sub-village has several Bayen traditions which are still preserved until now, such as ngapati, mitoni, brokohan, selapanan, akikah and routine practices every day before sunset. All of these traditions have their own meaning, purpose and manner of warning. This hereditary tradition can be said as a spiritual symbol that is actualized by the community while maintaining Javanese cultural heritage which is collaborated with religious teachings, namely Islam. This can be seen in its implementation by reciting Quran verses, including al-Insyirah and al-Qadr which are the focal points of the researchers in this study.

The first Bayen tradition is ngapati. The tradition of ngapati can also be called ngupati because one of the dishes is in the form of diamond (ketupat). In Javanese terms it is called ngapati because it coincides with the fourth month of pregnancy. This tradition is not only carried out by Javanese people but also by some Muslim communities in Southeast Asia. ${ }^{32}$ This ritual is celebrated by most scholars as the actualization of the hadith of human creation, where at forty-three days, or 120 days, the spirit is blown into the fetus. At the same time, their fortune, death and fate in the world were determined. In the explanation of the hadith, some scholars use it as a benchmark for not having an abortion if it reaches this 120th day, although some others say that an abortion is not permitted since there is life in the womb. ${ }^{33}$ At this important moment, the tradition of finding this was done, with the aim of asking God that the fetus in the mother's womb be given safety, a blessed age and a lucky life in the afterlife. In other words the tradition of ngapati is the point is to pray given all the goodness for the fetus. This tradition is carried out on Saturday night Wage (Friday Pon) which is close to the age of four months of the womb and is usually done at night, either after sunset or evening. This tradition is not carried out on a large scale, only by inviting magersari ${ }^{34}$ with approximately 15-20 people to pray together at the house of the pregnant mother. Led by the kiai, the program started with reading istighfar and creed, then surah al-Insyirah, al-Qadr, and al-Fatihah

${ }^{31}$ Muhammad Sholikhin, Rituals and Traditions of Javanese Islam, p. 50.

32 Ibid., p. 71.

33 Ibid., p. 75.

34 Neighbors whose homes are close together, or in the Javanese dictionary are interpreted as people whose homes are lodged in our yard. The meaning of the word is expanded penggunaannnya with neighbors whose homes adjacent to the house us . 
Millatī, Journal of Islamic Studies and Humanities, Vol. 4, No. 2, Desember 2019: 185-207

which were devoted to the Prophet Muhammad SAW, Sheikh Abdul Qadir al-jailani, Wali Mertongasono, mbah Dahlan and mbah Zaenuri and the spirits of families who have preceded as requested, and continued with reciting tablil that is closed with prayer. The recitation of tablil is always present in events in the Wonokerto hamlet, as birrul walidain to the predecessors, both parents and kiai who have died. Prayers are read in the form of tablil general prayers and special prayers for pregnant women. The menu presented in this tradition is diverse, including: sego golong, ${ }^{35}$ sego rosup ${ }^{6}$, confusion, sego grandchildren, ${ }^{37}$ ambeng, ${ }^{38}$ anointing, diamond, vegetable lodeh, free-range chicken egg. Menus are served in the number four or multiples, for example sego golong numbered four or eight, except sego rosul, ingkung, sego grandchildren, and ambeng which only amounted to one, because there are already many portions. For anointing must consist of four kinds of vegetables, the diamond must also have four sides, as well as a native chicken egg consisting of four fruits.

The second Bayen tradition is mitoni. At the age of pregnancy enters the seventh month, Javanese people call it "wes mbobot" or already weighted, already qualified. Because at this age the shape of the baby in the womb is perfect, while the mother has begun to feel the burden, this is now the tradition of Mitoni. It is called mitoni because in Javanese seven means pitu, so the age of seven months of pregnancy is called mitoni. There is also the mention of tingkeban taken from tingkeb means even or it's time, meaning that his age is even and is considered reasonable if born. This tradition does not have a special proposition which states the necessity of mitoni. It is the same as finding out where there is an important event that in these seven months the fetus is ready to be born, and the mother begins to experience a more severe pregnancy. The implementation of this tradition is almost the same as ngapati, what is different is the food menu that is served. If you find a kind of menu consists of four types, in this mitoni into seven types, with an additional closing menu, namely salad. For example in the anointing menu consisting of at least seven kinds of vegetables, or the diamonds there are also grandchildren (square) seven, as well as the number of native chicken eggs, amounting to seven. The unique thing about this mitoni that makes sauce a mother who is pregnant, if the result is good, in the sense that the sweet, salty and spicy dose is right then the conceived child is estimated to be a woman, if the opposite is a boy.

\footnotetext{
35 White, round rice is usually the size of a fist.

36 Yellow rice in the shape of a cone

37 White rice shaped cone

38 White rice topped with vegetables, fried tempeh, anchovies, and other side dishes served on rattan covered with banana leaves
} 
The third Bayen tradition is brokohan. The term brokohan is taken from Javanese word brokoh. It means offerings presented using a basket with two ears called brokoh. There are also those who claim that brokohan came from barakahan, or asked for barokah (blessing), which is to ask for prayer and blessings to Living scholars for the safety and goodness of infants. This tradition follows traditions that also existed at the time of the Prophet where the Prophet often visited by parents by bringing his baby to be asked for prayer and blessings, then the Prophet took the baby and gave his first chew to the baby, such as the hadith:

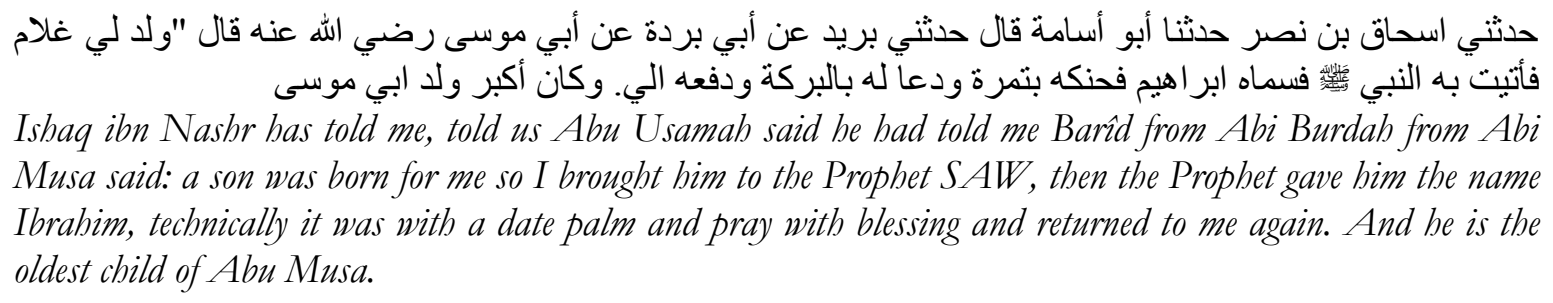
Musa said: a son was born for me so I brought him to the Prophet $S A W$, then the Prophet gave him the name Ibrabim, technically it was with a date palm and pray with blessing and returned to me again. And he is the oldest child of Abu Musa.

In this brokohan, the menu is the same as the density and mitoni, only there is no need to use how many types of vegetables in the anointing and no salad. The invitation to attend was the same, only attended by a few neighbors who were invited. The dish also does not use brokoh, but uses a round or large round pan. This event can be held right on the day of the baby's birth if possible, if the baby is born at the maternity home then it is held on the first day the baby is brought home. This event can be held in the morning, afternoon or evening depending on the request of the lavish owner Along with the times in Wonokerto itself this tradition is not always right on the day of the baby's birth, but see the circumstances and conditions that are possible, although still as soon as possible. If this event has been held then the name of the child can already be broadcast to others, and can already be used when slaughtering a married animal and shaving a baby's hair.

The fouth Bayen tradition is selapanan. If the baby's age enters the 35th day, then a tradition called weton is held. Weton is derived from the word wetu which means to be born, so it is a kind of commemorating the birthday. This birthday count is calculated in Java where weton is the day and the market meets again, which is for 35 days. Such as babies born on Tuesday legion, the weton commemorated is the next legion Tuesday, which is the next 35 days. Weton tradition is called selapanan for the first time. The tradition in the village of Wonokerto is carried out simply, namely by serving one large cone with ointment, anchovies, fried tempeh, and other equipment according to the owner's intent, to be enjoyed together by inviting the nearest neighbors, or more popular with the term ntik. Before the meal is eaten, prayers are read first by those considered the most elderly among those present, because the event is not by invitation, only by calling on 
Millatī, Journal of Islamic Studies and Humanities, Vol. 4, No. 2, Desember 2019: 185-207

neighbors to gather when the meal is ready. Before praying, reciting al-Fatihah, al-Insyirah, al-Qadr, alIkblas, al-Falaq, an-Nas and the verse of the chair, then close with prayer and eat together in one container. In this moment of selapanan, tablil is not usually recited to shorten the time.

The fifth Bayen tradition is akikah. Akikah is derived from the root word uquq which has several meanings, namely agate, broken, lawless and also means hair that grows on the head of a newborn baby. In the context of fiqh this final meaning is used, namely as a warning to shave baby's hair accompanied by slaughtering goats. In other words, the akikah has the connotation of slaughtering a goat in connection with cutting the hair of a newborn child, which is usually done on the seventh day of birth. This tradition is in accordance with the hadith of the Prophet which reads:

حدثنا ابو النعمان حدثنا حماد بن زيد عن أيوب عن محمد عن سلمان بن عامر قال عال: مع الغلام عقيقة. وقال حجاج حدثنا

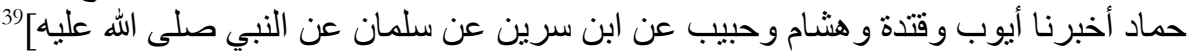
Abu Nu'man Has told us, Himad ibn Zaid has told us from Ayyub from Mubammad from Salman ibn 'Amir, said: to be with a boy is akikeah. And Hujaj said that he had told us Humad had told us Ayyub, Qatadah, Hisham and Habib from Ibn Sirrin from Salman from the prophet $S A W$.

The walimatul aqîqah event in Wonokerto was attended by more invitations than previous events. Attendees usually involve one RT and other invited guests. The event was led by a master of ceremony consisting of; opening, welcoming the lavish owner or representing as well as preaching what the baby's name is, reciting tablil dhiker, reciting the al-barzanji maulid in which later there is the process of cutting some baby's hair done by the elders or kiai who are present at the same time praying for the baby, and closing prayers. There is another small part by adding lectures or mau'idho hasanah before the closing prayer. The recitation of Surah al-Insyirah and al-Qadr at the event was conducted in conjunction with the tahlil dhikr which was read at the beginning before the start of a series of recitation of tablil. Both of these surahs are read to open the tablil which was preceded by the recitation of istiffar and creed. Cutting baby's hair is not only done by one person, depending on how many people are considered elderly or how many kiai are present at the event, or close family babies such as grandfather and others depending on demand. The hair that has been cut is then dipped in flower water and placed in rice that has been provided before, in the hope of a fragrant life (good) and easy to find good fortune. The shaved hair was once weighed to be given alms by parents to people in need. But the fact is now no longer using the scales, only approximately how much alms will be issued. Then the hair along with rice and water to wash it are buried together

\footnotetext{
${ }^{39}$ Hadith no. 5471, "Kitab al-Aqîqah", Abi Abdillah Muhammad bin Ismail al-Bukhori, al-Jami 'ash-Shohih , p. 450.
} 
with baby bathir or placenta that has been buried before. For the menu presented there are no special rules other than the slaughtered goat, and other complementary menus are left to the event owner.

The sixth Bayen tradition is routine before Maghrib. One of the Bayen traditions that is not commonly found elsewhere is the recitation of Surah al-Insyirah and al-Qadr routinely every day. The time used is before sunset, read by his family, can father, mother, grandfather or grandmother. The baby is on the lap and is recited the two surahs that previously began with the surah al-Fatibah, and some are added to the verse of the chair, then blown to the crown. After this reading the baby is kept in a state of lap until after sunset. This condition applies to babies who have not been able to crawl, because the conditions will change when the baby no longer wants to stay in his lap. He read two surahs it lasts until the baby is aged one year or more. There are also those who still recite it until the child can recite it himself at the same time to make it a habit to read verses of the Quran.

\section{Transmission and Transformation of the Practice of Reciting Surat al-Insyirah and al-Qadr in the Bayen Tradition}

The tradition of reciting surah al-Insyirah and al-Qadr in Bayen does not come in a vacuum. This teaching also does not necessarily exist and live to this day without any things that are like it. As a community whose life is dynamic, the Wonokerto community both consciously and unconsciously participated in forming and preserving these teachings until they can still be found today. The transmission and transformation of a tradition, in this case Bayen, that occurs in the Wonokerto community cannot be separated from the process of interfaith relations as the bearer of teachings, the community as actors and the changing environmental conditions. As Peter L Berger said that society is a product of human activity which then acts back to humans themselves, or in other words humans produce society and society produces humans. ${ }^{40}$ From the other side, Berger \& Chaffe (in Craig \& Muller, 2007) explained that the communication is considered as the process of expression, interaction, and influence, which is in the process of human behavior or other organisms expressing psychological mechanisms, circumstances, temperament (trait), and through interactions with other individuals and produce cognitive, emotive, and behavioral impacts. ${ }^{41}$ Dialectical relations between all components of society have their respective roles in the process of transmission and transformation of the practice of reading the Surah al-Insyirah and al-Qadr in

\footnotetext{
40 Peter L Berger and Thomas Luckman, Social Interpretation of Reality, p. 83.

${ }^{41}$ Karman, Contruction of Social Reality as Though Movement (Theoretical Review on Social Construction of Reality Peter L. Berger) Journal of Research and Development Communication and Information Volume 5 No. March 3
} 
Millatī, Journal of Islamic Studies and Humanities, Vol. 4, No. 2, Desember 2019: 185-207

the Bayen tradition. To see clearly how this process works, the researcher will review it using Peter L. Berger's dialectical triad theory, as follows:

The first is externalization. Each individual has their own way of expressing the knowledge they have gained. This expression is formed from the journey of a person's life which is met with new knowledge that he gained in his journey. This expression can sometimes be a certain identity in a person. ${ }^{42}$ It becomes inevitability that someone, say in this case the kiai who is a role model of the community, once was in the position of a santri (students/follower) who sought role models for his kiai. When he became a santri by having the role model of a kiai, that's when the imitation process took place. This process of imitation will later become a part of a kiai's who sometimes determines how he responds to things. Berger states that further knowledge will guide someone in their daily lives. ${ }^{43}$ Almost all the kiai have experienced the position of santri, as well as the simbah of $\mathrm{KH}$ Dahlan, the kiai who brings the practice of reading manakib to the people of Wonokerto. Studying with the kiai both from boarding in Nganjuk, East Java to learning tarekat and taking allegiance to $\mathrm{KH}$ Muslih Abdurrohman Mranggen, led Dahana kiai to become a religious figure whose faith was won by the Wonokerto people. His da'wah field was not limited to Wonokerto Village, but to several places outside the sub-district even though there was no adequate transportation at that time. ${ }^{44}$ In the social world, Kiai Dahlan not only plays the role of a murshid (leader) of the congregation who teaches him, but also acts as a mosque imam where the Wonokerto people carry out religious activities, although not all follow the tarekat he fostered. Having nyantri or school experience in several places, all of which are pesantren or islamic boarding school with traditional educational patterns, makes mbah Dahlan can be populist despite his position as a kiai. Sitting with the community listening and participating in thinking about the problems they face, makes the bond between the kiai and the community seem inseparable. Being a religious figure and at the same time having a congregation congregation, there is also a great opportunity for mbah Dahlan to teach the practices of the tarekat that are felt by the general public. One of the practices of the tarekat which he also conveyed to the public was the reading of the Manakib on the anniversary of marriage and birth. Mbab Dahlan, when studying the tarekat to mbah Musleh Mranggen, received the deed ijazah and at the same time was provided with a number of practices that accompanied the Manakib, one of which read the surahs of choice according to the purpose of reading the

42 Muhammad Barir, Al-Quran Tradition in Coastal, cet I, (Yogyakarta: Nurmahera, 2017), p. 200.

43 Peter L Berger and Thomas Luckman, Social Interpretation of Reality, p. 27.

${ }^{44}$ Interview with mbah Muhtarom, student and right hand mbah Dahlan, on 29 July 2018 
manakib. From Mbah Muslih, the practice of reading manakib contains the motivation of love and taboo against one of the trustees, Sheikh Abdul Qadir al-Jailani. This practice can be sustained at any time and for any purpose, not limited to special warnings, such as birth and marriage. ${ }^{45}$ Mbab Dahlan carried the practice and delivered it to the community in the form of his interpretation which was adapted to the needs of the Wonokerto community at that time, where the Wonokerto community had various kinds of customs and traditions that were perpetuated from before he became a kiai, including in commemorating marriage and birth. In the hadith about the creation of man as narrated by Bukhori, there are three things that every human being inevitably experiences, births, dies and is resurrected after death. In the process of birth itself, experiencing urgent phases in which determined deeds, fortune, and good and bad luck when Living in the world later. From this hadith, several spiritual traditions and warnings emerge in order to invoke goodness in all that will happen. In Wonokerto, a ceremony commemorating these urgent moments was held, namely in the process of birth and death. The moment that is no less important is also celebrated in the moment of marriage, where like birth there will be a new family born after the marriage. Because deeds and rizki have been outlined long before a baby is born, it is necessary to hold a special prayer to expect goodness in the good fortune and safety of life in the world. Kiai Dahlan saw this as an opportunity to incorporate the value of the teachings of the tarekat into the existing traditions of society. Because the anniversary of birth and marriage is held with the aim of the safety of newborn babies and new families and facilitated life and prosperity in the next life, the practice taught by Mbah Dahlan is reading manakib accompanied by choice surahs aimed at opening the door to good fortune and safety, namely by read Surah al-Fatihah, al-Insyirah, al-Qadr, al-Ikhlas, al-Falaq, and an-Nas before reading manakib. While at another important moment that is death and resurrected from the grave, the warning is filled with the reading of the surah Yasin and tablil, along with fida 'Kubro in the hope of being forgiven of sins and given a high place by God for those who have died. The practice of reading out the chosen surahs accompanied by the Mankind was the result of Kiai Dahlan expression in pouring knowledge about the benefits of reading the Mankind he had previously obtained. The selection of the surahs that were read before the Manakib was an interpretation of previous knowledge which was met by the needs of the community, namely the hope of ease of Living and being given life safety. This practice did not stop at his time, but was handed down to one of his sons who continued the leadership of the tarekat, namely KH Zaenuri

${ }^{45}$ Muslih bin Abdurrohman, an-Nûr al-Burbani: fi Tarjamati al-Lujjaini ad-Dâni fi Dziłkri Nubdzatin min Manâkibi asSheikh Abdul Qodir al-Jailani, juz 1 (Semarang: Karya Thoha Putera, 1961) , p. 97-104. 
Millatī, Journal of Islamic Studies and Humanities, Vol. 4, No. 2, Desember 2019: 185-207

Dahlan. Mbah Zaenuri, as he is usually called, is one of the sons of $\mathrm{KH}$ Dahlan who received the relay as the mosque's imam and murshid of the tarekat. Like a person who was prepared to be a kiai, Mbah Zaenuri was also sent to a pesantren to study, even though his father was a kiai. In terms of religious traditions, not much has changed in the Wonokerto community, although there have been changes in the implementation of both place and time, but they have not changed the procession. In the case of the practice of the tarekat, especially the reading of the Manakib, Mbah Zaenuri did not make changes and only continued what his father had pioneered from the beginning. This is because the pattern of education which mbab Zaenuri get almost the same as what is learned mbah Dahlan during become students. Being in an area far from the city center and not many are able to continue their education higher than junior high school in formal schools, a factor does not need a lot of changes in religious traditions that have existed before. Kiai Nurul Huda, received the next relay when Mbab Zaenuri started to get sick and could not lead the mosque. Becoming a santri in several regions, some of which were pesantren, his father used to study, namely in Bendo Kediri, and Pulutan in Salatiga City. In addition, Kiai Nurul Huda also studied Mbab Tadzkir and mbah Nawir, who are now one of the scholars in Salatiga, as well as studying at Islamic Senior High School (MAN) in Salatiga. It didn't stop there, Kiai Nurul Huda also continued his tertiary education at STAIN Salatiga (now IAIN Salatiga) and continued his master's degree at the same place. Having busy teaching and still continuing formal education, kiai Nurul Huda cannot be at all times in Wonokerto. His absence at each of these events affected the implementation of several traditions that previously existed. One tradition that has undergone a transformation since $\mathrm{KH}$ Zaenuri died was the tradition of reading manakib on the anniversary of birth and marriage. The implementation of the reading of the manakib which is usually read by the kiai, because of the absence of the kiai Nurul Huda, makes the reading of the manakib impossible. Besides that, from the kiai Nurul Huda himself, he had not yet obtained the certificate of reading from the father, for several reasons. For this reason, in both warnings, the reading of the book was abolished. Having a salaf pesantren educational background and formal education outside the pesantren, even to tertiary institutions, makes kiai Nurul Huda more open to new things that are developing. Even the Wonokerto people are starting to get to know the outside world of children who continue their higher education outside the city, making a number of changing life patterns. In connection with the eradication of the reading of the Manakib, Kiai Nurul Huda interpreted the practice, where the motivation brought was mababbah and tabarukan, while at the same time begging for easy Living and safety. For Kiai Huda, this motivation and purpose can 
still be achieved even without reading the manakib, namely by reading the elective surahs that preceded him, especially Surah al-Insyirah and al-Qadr. Both of these surahs have the specific purpose of making things easier. Seeing the conditions in which the Wonokerto community was also busy and the number of family heads working outside Java so that the invitation to attend the event was reduced, the commemorative events were made even simpler. Expression of knowledge of kiai Huda in this matter, he also applied in several warnings, not only in births and marriages, for example selametan people who will start work, or walimatussafar for the hajj and so forth related to people who are still alive. In other words, every warning that aims to pray for people who are still alive, is added to the two surahs, and to send prayers of the dead is recite tablil and or surah Yasin. ${ }^{46}$ The recitation of the two surahs basically comes from the privilege of the surah used to facilitate the fortune as well as the safety and smoothness of what will be done, so that every prayer for people who are still alive the two surahs are read, because the true hopes of the Living are included in it . This means that these two surahs can be said for people who are still alive, including a surah that 'sweeps the universe', or covers all life goals. The privilege conveyed by the kiai Nurul Huda is in accordance with what is written in several literatures, including in the book of Abwab alFaraj by Muhammad bin 'Alawi al-Maliki al-Husaini mentioning in the tilawatil Quran chapter, khudz. min al-Quran ma Syi'ta five Syi'ta mentioned the efficacy of al-Insyirah among them

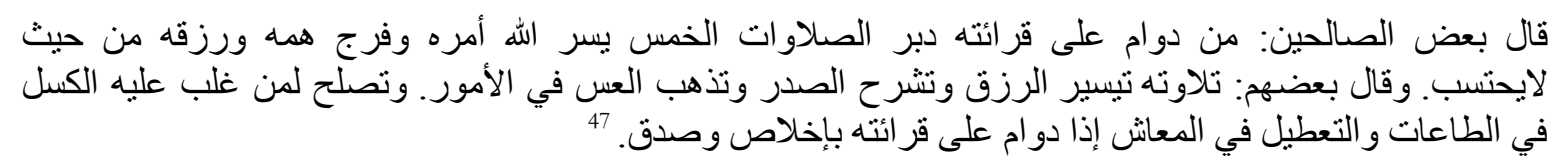
Some pious people say: whoever perpetuates his reading during the five daily prayers then Allah facilitates his affairs and dispels his sadness and gives countless benefits. And some say: read it makes it easy and light up the chest and eliminate the trouble of all matters. And treat those who are stricken with laziness in obedience and difficulty in inhalation if they perpetuate their readings with sincerity and trust.

The same privilege is also in Surah al-Qadr which is usually juxtaposed with al-Insyirah. In the book Khorinatul asror mentioned that the Prophet Muhammad SAW once said:

" Whoever reads Al-Qodr 100 times then Allah SWT will put his great name into the heart of the person who reads it and all his requests will always be granted. "18

${ }^{46}$ Interview with kiai Nurul Huda, on 2 August 2018

${ }^{47}$ Muhammad bin 'Alawi al-Maliki al-Husaini, Abwäb al-Faraj, (Beirut: Dar al-Kutub al-'Ilmiah, 1971), p. 113.

48 Muhammad Haqqi an-Nazily, Khozinatul Asrar, (Beirut: Dar al-Kutub al-Ilmiyyah, tt) android application in http://play.google.com/store/apps/details?id=com.mulusrahayu. Kitabkhozinatulasror Complete / 
Millatī, Journal of Islamic Studies and Humanities, Vol. 4, No. 2, Desember 2019: 185-207

Privileges for those who recite the two surahs can be used as a reason why the two surahs are recited, especially in the moment of birth and marriage, where both moments of the start of a new life require a strong spirit and a handle in living a life that is no longer the same as the previous life.

The second is objectivity. In the objectivity process a person will successfully become part of the process of transmission and transformation if his knowledge has been agreed in a particular society and is legitimized in a concrete action carried out collectively. Mutually agreed upon and carried out on an ongoing basis, making the expression of knowledge become a new form of community behavior. ${ }^{49}$ The form of success of the kiai in Wonokerto in expressing his knowledge is seen in the religious traditions that live in the Wonokerto community. The recitation of Surah alInsyirah and al-Qadr is the result of the objectivity process of the results of the understanding brought by the kiai and the understanding of the people who obeyed the kiai, which eventually resulted in a tradition which was carried out together. These forms of objectivity are seen in the whole package of the Bayen tradition, starting from the density, mitoni, brokoban, akikah, selapanan, until the routine before sunset with the implementation of the procedure that the researcher described in the previous chapter. In the tradition of Sociology, it is stated that ordinary people take for granted " the realities" that are very different between one society and another. By the logic of the discipline, a sociologist is forced to ask, at the very least, what the difference between the two "realities" might be understood in terms of the differences that exist between the two societies. On the other hand, philosophers obliged by their profession to not take anything for granted, and to obtain maximum clarity on the status of the most basic of what ordinary people regarded as "reality" and "knowledge"..$^{50}$ The externalization and objectivity processes in a society are moments in a dialectical process that takes place continuously. ${ }^{51}$ In the process, because the conditions of society are also not the same from time to time, the results of this dialectical process also changes. Externalization experienced by the community during Kiai Dahlan to Kiai Nurul Huda experienced differences. The recitation of Surah al-Insyirah and al-Qadr, which used to be a package with the reading of the Manakib, in its development actually eliminated the reading of the Manakib by not eliminating its original purpose. The abolition of the reading of the Manakib became a new tradition that could be said to be independent of the previous tradition agreed upon by the community and carried out jointly. In this objectivity process, the kiai perform ijtihad on their individual knowledge which is

\footnotetext{
${ }^{49}$ Muhammad Barir, Tradition of the Quran on the Coast, p. 202.

50 Aimie Sulaiman, Understanding Peter L. Berger's Social Construction Theory, Journal of Society, Volume VI, Number I, June 2016

51 Peter L Berger and Thomas Luckman, Social Interpretation of Reality, p. 83.
} 
then spread and followed by the community together so that it becomes a social action that regulates the life together. ${ }^{52}$ Various facts and knowledge both from the kiai and the community that were initially individual and subjective experienced a process of externalization in social interaction, working together which later became part of community activities. The social reality in the form of intersubjective experience then experiences an objectivity process and is institutionalized which then becomes an objective reality that is agreed upon and carried out together. The receipt of a knowledge institutionalized in a society in the form of tradition means that the knowledge has gained sociological legitimacy, marking the realization of the basic integration of the knowledge of all socio-cultural groups. ${ }^{53}$ This eliminates subjective principles from individual interests, so that the resulting tradition is objective. ${ }^{54}$ This principle of objectivity determines a new social order which not only reinforces the existing patterns of habits and behavior in society but is aimed at directing desired goals and eliminating habits that are already incompatible and creating new religious patterns that are more in harmony with the state of society and the times. ${ }^{55}$

The third is internalization. The externalization and objectivity processes are moments in a continuous dialectical process. The third moment in this process is the internalization, the moment where social world that has been objectified put back into its constituent public consciousness during the process of socialization. ${ }^{56}$ In this moment, every individual in society cannot let go of his subjectivity. In a society that has a certain ideology, each person will understand the ideology differently. ${ }^{57}$ The Wonokerto people are the main players in knowing the internalization of the Bayen tradition, especially in reading the Surat al-Insyirah and al-Qadr. The researcher conducted interviews with people from various back ground education and occupations. Carrying out the Bayen tradition has become an obligation that is never neglected by every pregnant woman in Wonokerto, from all walks of life. This Bayen tradition is an agenda that if not implemented becomes unusual. Although the implementation is not always timely, a series of Bayen traditions becomes a kind of separate debt if not done immediately. Each community has their own reasons for implementing the tradition. From the peasants who make up the majority of the Wonokerto community, they see this tradition as a natural thing that is certain to be done to pray for the mother

${ }^{52}$ Frans M. Parera, "Exposing the Mysteries of Humans as Homo Fabers", Social Interpretation of Reality, ed. Peter L Berger and Thomas Luckman, p. xii.

53 Ibid., p. 118.

${ }^{54}$ Sirajudin, Manakib Legislation in Indonesia, (Yogyakarta: Student Library, 2008), p. 35.

55 Mudzakir, "Manakib in Indonesia in the Peter L. Berger Social Construction Perspective", $A L-' T S A L A H$ Vol. XII, No. 1, June 2014 , p. 167.

${ }^{56}$ Peter L Berger and Thomas Luckman, Social Interpretation of Reality., p. 83.

${ }^{57}$ Muhammad Barir, Tradition of the Quran on the Coast, p. 203. 
Millatī, Journal of Islamic Studies and Humanities, Vol. 4, No. 2, Desember 2019: 185-207

and the baby they are carrying. This tradition must exist in order to ward off various invisible negative things that can approach pregnant women and their babies. Even though this tradition is on the agenda, it does not cost much, usually they don't feel any objection to it. Instead they use this opportunity to share with neighbors who cannot be done every day. The same expression is also obtained by the researchers from the community who work as teaching staff at various levels of the school. According to them, the Bayen tradition becomes the first obligation that families must fulfill for their baby to be born into the world. How the baby's life in the womb and after birth no one can guarantee safety and perfection besides the Creator. For this reason the Bayen tradition which contains prayers of salvation needs to be done to get closer and ask for kindness from the Creator. Especially in this Bayen commemoration of the surahs that are read, especially al-Insyirah is a surah that is usually read to ask for fluency in all matters, while al-Qadr is a complementary glory such as eveatul qadr. Some other states that the contents of the last verse in Surah al-Qadr which

reads سَلْمُ هِيَ حَتَّى مَطْلَع الَفَْجْرِ contains prayers of salvation until tomorrow that is suitable to be read to the baby before or at night. The internalization of this tradition is also the researcher gets from housewives who certainly feel the ups and downs of pregnancy. The majority stated that something was lacking when the Bayen tradition was not carried out when they were pregnant to give birth. Pregnancy is a condition that is not all can be explained in plain view. The condition that according to them cannot be explained is what makes pregnant women need other strength outside their physical strength, namely prayers offered by people around. This is supported by Living in the middle of Javanese society which is rich in myths especially about pregnancy which can only be resisted with spiritual power.

The Bayen tradition, which is full of safety prayers for both the mother and the baby, is a special force needed by every pregnant woman in Wonokerto. Although not all pregnant women know about the implementation of the tradition that is usually attended by men, they believe that the tradition is very useful for their safety and their womb. Apart from the recitation of Surah al-Insyirah and al-Qadr in this series of Bayen traditions, there are also people who practice it not at these times. For example there are those who read it when the child is asleep and wake up from sleep while holding the child's chest to fortify the child from bad desires. Holding the chest as a picture that lust out of the heart, for that when reciting al-insyirab and al-Qadr directed to the heart. There are also those who read it when the child is facing an exam, so that intelligence is given to the brain to learn and fluency in working on exam questions. Broadly speaking, the transmission of the practice of reciting al-Insyirah and al-Qadr occurs through three kiai in Wonokerto, namely KH Dahlan, KH 
Zenuri Dahlan and Kiai Nurul Huda. This transmission is passed down through an ijazah. In the process of transmission, this tradition underwent a transformation that was originally intact, namely the reciting of selected surahs and manakibs, to the point of simply reciting al-Insyirah and al-Qadr only. This transformation occurs because each kiai has an educational background that is not all the same, and is met by the conditions of the people who are also experiencing changes. The expression of knowledge of each kiai is based on the externalization they previously carried out so as to form each type and mindset that is different in Living and interpreting a matter. This different externalization and internalization is one of the factors that a tradition undergoes a transformation in its transmission process, from the beginning taught until practiced until now.

\section{CONCLUSION}

Based on the previous discussion as contained in the chapters in this study, then some conclusions can be drawn as follows: The Bayen tradition is all things related to infants, starting from the womb until born into the world, starting to be ngapati, mitoni, brokohan, selapanan, akikah and routines before Maghrib. Each tradition is carried out at different times. The order of implementation starts with reciting istighfar and creed, then surah al-Insyirah, al-Qadr, and al-Fatihah which are devoted to the Prophet Muhammad, Sheikh Abdul Qadir al-Jailani, Wali Mertongasono, mbah Dablan and Mbab Zaenuri, and family spirits that have been devoted to the Prophet Muhammad, Sheikh Abdul Qadir al-Jailani, Wali Mertongasono, mbah Dahlan and Mbah Zaenuri, and family spirits who have been devoted precede according to request, and proceed with the reading of tahlil that is closed with prayer. In Akikah is added with the reading of driba al-Barzanji, then for the routines before sunset it is only recited surah al-Insyirah and al-Qadr and then blown to the crown of the baby. This research proves that the study of the Quran is not only limited to the textual side, but rather to the social reality in which the Quran lives in society. Living Quran for the benefit of this praxis widens the study of the Quran integrated with social sciences.

\section{REFERENCES}

\section{Books and Scientific Work}

Abdullah, Amin. Studi Agama; Normativitas atau Historisitas, (Yogyakarta: Pustaka Pelajar, 1996). 
Millatī, Journal of Islamic Studies and Humanities, Vol. 4, No. 2, Desember 2019: 185-207

Abdurrohman, Muslih bin. an-Nûr al-Burhâni: fi Tarjamati al-Lujjaini ad-Dâni fi Dz̧ikri Nubdzatin min Manâkibi as-Syeikh Abdul Qodir al-jailâni, juz 1 (Semarang: Karya Thoha Putera, 1961).

Berger, Peter L. .Langit Suci, Agama sebagai Realitas Sosial, tjmh. Hartono, (Jakarta: LP3S, 1994) dan Thomas Luckman. Tafsir Sosial Atas Kenyataan, tjmh. Hasan Basari, Jakarta: LP3ES, 2013)

Barir, Muhammad. Tradisi al-Qur'an di Pesisir, cet I, (Yogyakarta: Nurmahera, 2017)

al-Bukhori, Abi Abdillah Muhammad bin Ismail. al-Jami' ash-Shohih, Jilid 2, (Kairo: al-Mathba'ah asSalafiyah).

Dimyati, Mohamad. “Al-Qur'an sebagai Realitas Sosial” (Kajian Sosiologis Atas Masyarakat Muslim Desa Sukorejo-Trenggalek), Tesis UIN Sunan Kalijaga, 2009. Tesis tidak diterbitkan

Ernita Dewi, Tranformasi Sosial dan Nilai Agama, Jurnal Substansia, Vol. 14 no. 1 April, 2012

al-Husaini, Muhammad bin 'Alawi al-Maliki. Abwāb al-Faraj, (Beirut: Dar al-Kutub al-'Ilmiah, 1971).

Koentjaraningrat. Pengantar Ilmu Antropologi, (Jakarta: Aksara Baru, 1989).

Mansur, Living Qur'an dalam Lintasan Sejarah Studi Qur'an” Metodologi Penelitan Living Qur'an dan Hadis”, ed. Mansur, dkk, cet. I, (Yogyakarta: TH-Press, 2007).

Mudzakir, "Hukum Islam di Indonesia dalam Perspektif Konstruksi Sosial Peter L. Berger", AL'ADALAH Vol. XII, No. 1, Juni 2014.

Muniroh, Nisfu Sya’ban dalam Tradisi Masyarakat Banjar ( Studi Living Hadis Perspektif Sosiologi Pengetahuan Peter L.Berger ), Jurnal Al-Risalah Volume 13, Nomor 1 January-June 2017

Parera, Frans M. "Menyingkapi Misteri Manusia sebagai Homo Faber”, Tafsir Sosial Atas Kenyataan, ed. Peter L Berger dan Thomas Luckman. tjmh. Hasan Basari, (Jakarta: LP3ES, 2013)

Shihab, Quraish. Tafsir al-Misbah; Pesan, Kesan dan Keserasian al-Qur'an ${ }_{s}$ cet. V, Vol. 8 (Jakarta: Lentera Hati, 2002). 
Recitation of Surah al-Insyirah and al-Qadr in the Bayen Tradition ..... (Annisa Fadlilah)

Tafsir al-Misbab; Pesan, Kesan dan Keserasian al-Qur'an ${ }_{s}$ cet. V, Vol. 15 (Jakarta: Lentera Hati, 2002).

ash-Shobuni, Ali. Shofwatu at-Tafâsîr, Jilid III, cet. X, (Cairo: Dar ash-Shobuni, 1980).

Sholikhin, Muhammad. Ritual dan Tradisi Islam Jawa, (Yogyakarta: NARASI, 2010).

Sirajudin, Legislasi Hukum Islam di Indonesia, (Yogyakarta: Pustaka Pelajar, 2008).

as-Suyuti, Asbab an-Nu₹ul, jilid II, (Kairo: Dar al-Fajr li at-Turats, 2010).

Syamsudiin, Sahiron. "Ranah-ranah Penelitian dalam Studi al-Qur'an dan Hadis" Metodologi Penelitan Living Qur'an dan Hadis", ed. Mansur, dkk, cet. I, (Yogyakarta: TH-Press, 2007).

Yusuf, Muhammad. "Pendekatan Sosiologi dalam Penelitian Living Qur'an" Metodologi Penelitan Living Qur'an dan Hadis', ed. Mansur, dkk, cet. I, (Yogyakarta: TH-Press, 2007).

Zeitlin, Irving M. Memahami Kembali Sosiologi; Kritik Terbadap Teori Sosiologi Kontemporer, (Yogyakarta: Gajah Mada Univercity Press, 1998).

\section{Website}

https://kamuslengkap.com/kamus/jawa-indonesia/arti-kata/bayen, acsessed on 15 Dec 2017

an-Nazily, Muhammad Haqqi . Khozinatul Asrar, (Beirut: Dar al-Kutub al-Ilmiyyah, tt) android aplication

on http://play.google.com/store/apps/details?id=com.mulusrahayu.kitabkhozinatulasrorlengkap $L$ 